\title{
Food-induced anaphylaxis among a population of adolescents - Report from the BAMSE survey
}

Mirja Vetander ${ }^{1,2,3}$, Jennifer L.P. Protudjer ${ }^{2,3^{*}}$, Gunnar Lilja ${ }^{3,4}$, Inger Kull ${ }^{2,3,4}$, Marianne van Hage ${ }^{5}$, Anna Bergström², Eva Östblom ${ }^{3,4}$, Magnus Wickman ${ }^{1,2}$

From Food Allergy and Anaphylaxis Meeting 2014

Dublin, Ireland. 9-11 October 2014

\section{Background}

The epidemiology and early-life risk factors of foodinduced anaphylaxis ("anaphylaxis") in adolescence are incompletely understood.

\section{Objective}

To study aspects and early-life risk factors of foodinduced anaphylaxis amongst adolescents.

\section{Methods}

Parent-reported questionnaire data from 2-3 months, and 1, 2 and 16 years from a large birth cohort were used $(\mathrm{N}=3153)$. Immunoglobulin $\mathrm{E}$ to 14 common allergens were analysed at $4(\mathrm{n}=2283)$ and 16 years $(\mathrm{n}=2510)$. In a subset of 371 adolescents, 15 additional food allergen extracts or components were analysed at 16 years. Data on dispensed adrenaline autoinjectors and inhaled steroids were extracted from a national register. Severity of food reactions and asthma were defined. The incidence of anaphylaxis was analysed in association with early-life risk factors.

\section{Results}

In the 12 months prior to the study, $8.5 \%$ of adolescents reacted to food and $0.8 \%$ had anaphylaxis; the annual incidence of the latter was $761 / 100,000$ person years. Only one-third of adolescents when experiencing anaphylaxis had contacted healthcare. Restricting analyses to these adolescents yielded an annual incidence of 240/ 100,000 person years. In the 24-months prior to the study, adrenaline autoinjectors were dispensed for $67 \%$ of those with reported symptoms defined by us as anaphylaxis according to international guidelines. The strongest early-life risk factors for anaphylaxis included

\footnotetext{
${ }^{2}$ Institute of Environmental Medicine, Karolinska Institute, Stockholm, Sweden
} Full list of author information is available at the end of the article sensitisation to foods at 4 years $(\mathrm{OR}=20.9,95 \% \mathrm{CI} 6.8$ 64 ) and food reactions (OR=17.7, 95\%CI 6.91-45.2) between 1-2 years.

\section{Conclusion}

Anaphylaxis in adolescence is more common than previously reported in the literature. Early-life sensitisation and reactions to foods increase anaphylaxis risk in adolescence by more than 15 -fold.

\section{Authors' details}

'Sachs' Children and Youth Hospital, Stockholm, Sweden. ${ }^{2}$ Institute of Environmental Medicine, Karolinska Institute, Stockholm, Sweden. ${ }^{3}$ Centre for Allergy, Karolinska Institute, Stockholm, Sweden. ${ }^{4}$ Department of Clinical Science and Education, Södersjukhuset, Karolinska Institute, Stockholm, Sweden. ${ }^{5}$ Clinical Immunology and Allergy Unit, Department of Medicine Solna, Karolinska Institute and University Hospital, Stockholm, Sweden.

Published: 30 March 2015

doi:10.1186/2045-7022-5-S3-O25

Cite this article as: Vetander et al:: Food-induced anaphylaxis among a population of adolescents - Report from the BAMSE survey. Clinical and Translational Allergy 2015 5(Suppl 3):O25.

Submit your next manuscript to BioMed Central and take full advantage of:

- Convenient online submission

- Thorough peer review

- No space constraints or color figure charges

- Immediate publication on acceptance

- Inclusion in PubMed, CAS, Scopus and Google Scholar

- Research which is freely available for redistribution

Submit your manuscript at www.biomedcentral.com/submit
() Biomed Central 